\title{
Why it is difficult to treat and prevent drug-resistant hypertension and elevated pulse pressure: the unrecognized roles of ionized hypomagnesemia, nitric oxide, ceramides, platelet-activating factor,and epigenesis
}

Keywords: metarterioles, orthotopic, microvasculatures, atherogenesis

\section{Introduction}

In today's world, there is a growing prevalence of drug-resistant hypertension (DRH). Although numerous anti-hypertensive drugs keep-being designed by pharmaceutical and biotech companies, there is not, as yet, any one, two, or three drugs when taken together that will consistently lower and maintain both a near-normal systolic (SBP) and diastolic (DBP) arterial blood pressure in DRH patients. ${ }^{1,2}$ This failure to be able to consistently lower SBP and DBP, in DRH patients, has been attributed to the latter being of precise, unknown origin. Many of these patients are obese, diabetic, and/or demonstrate defective kidneys hence are usually treated with diuretics, anti-diabetic drugs, beta-blockers, calcium channel blockers and renal drugs, told to undergo lifestyle changes, and placed on strict weight-loss diets..$^{1,2}$ But despite these measures and therapies, they rarely return SBP and DBP towards normal.

It is generally agreed that age-related increases in arterial blood pressure (ABP) are mainly a reflection of an increase in SBP while maintaining or exhibiting a slight increase in DBP. This situation results in a widening of pulse pressure (PP) which is usually a cardinal sign seen in DRH patients. Whatever the exact cause, this often leads to atrial fibrillation (AF), stiffness of arterial vessels, and is associated with developing atherogenesis, and coronary arterial disease, a heart attack, or a stroke.

Approximately 60 years ago, two of us, using diverse mammalian isolated arterial blood vessels, found that lowering the magnesium ion $\left(\mathrm{Mg}^{2+}\right)$ concentration in oxygenated Krebs-Ringer bicarbonate solution, surprisingly, would cause contraction; the lower the $\mathrm{Mg}^{2+}$, the greater the development of contractile force and vasoconstriction. ${ }^{3-}$ ${ }^{17}$ After several of our findings were published, numerous other laboratories corroborated our reports. ${ }^{18,19}$ Approximately 35 years ago, our laboratories, using rats subjected to dietary deficiency of $\mathrm{Mg}$, observed a progressive elevation in $\mathrm{ABP}$ with a progressive widening of PP.

\section{Importance of dietary $\mathbf{m g}$ deficiency and $\mathrm{mg}$-deficient environments to elevation in sbp, $\mathrm{dbp}$ and $\mathrm{pp}$}

Our group and others have reported, in several studies, that aging human subjects (from infants to the elderly) demonstrate a progressive decline in both total $\mathrm{Mg}$ and total ionized serum $\mathrm{Mg}\left(\left[\mathrm{Mg}^{2+}\right]_{0}\right)$; with the ionized fraction showing the greatest, progressive decline. ${ }^{20-26}$
Volume 5 Issue 2 - 2020

\author{
Burton M Altura, ${ }^{1-7}$ Asefa Gebrewold,' \\ Anthony Carella,' Aimin Zhang,' Wenyan Li,' \\ Tao Zheng,' Lawrence M Resnick, ${ }^{8}$ Nilank C \\ Shah, ${ }^{1,5}$ Gatha J Shah, ${ }^{1,5}$ Bella T Altura ${ }^{1,3-7}$ \\ 'Department of Physiology and Pharmacology, State University \\ of New York Downstate Medical Center, USA \\ 2Department of Medicine, State University of New York \\ Downstate Medical Center, USA \\ ${ }^{3}$ Cardiovascular and Muscle Research, State University of New \\ York Downstate Medical Center, USA \\ ${ }^{4}$ The School of Graduate Studies in Molecular and Cellular \\ Science, The State University of New York Downstate Medical \\ Center, USA \\ ${ }^{5}$ Bio-Defense Systems, Inc, Rockville Centre, USA \\ ${ }^{6}$ Orient Biomedica, Estero, USA \\ 7 Magnesium for Health Foundation, Patterson, USA \\ ${ }^{8}$ Department of Medicine, Cornell University College of \\ Medicine, USA
}

Correspondence: Professor Altura BM, Department of Physiology, Pharmacology \& Medicine, State University of New York, Downstate Medical Center, Brooklyn, New York I I 203, USA, Tel 7|8-270-2194, Email baltura@downstate.edu

Received: May 13, 2020 | Published: May 29, 2020

The older the test subject, the lower the $\left[\mathrm{Mg}^{2+}\right]$ in both cells and sera. The serum ionized $\mathrm{Mg}$ is the most significant as it parallels that of many tissue and cellular levels of free ionized $\mathrm{Mg} .{ }^{26}$ Those subjects with either type 2 diabetes mellitus, coronary arterial disease, on renal dialysis, gestational diabetes, renal transplant recipients (with hypertension), orthotopic liver transplantation, pregnant women with transient hypertension during labor, or DRHs demonstrate the greatest declines in $\left[\mathrm{Mg}^{2+}\right]_{0}$ and intracellular free $\mathrm{Mg}\left(\left[\mathrm{Mg}^{2+}\right]_{\mathrm{i}}\right){ }^{26-36}$ Previously, in multiple human studies, we documented that serum ionized $\mathrm{Ca} /$ $\mathrm{Mg}$ ratios are indicative of peripheral vasoconstriction and increased vascular reactivity to circulating neuro-humoral vasoconstrictor amines and peptides. ${ }^{37-40}$ The results of these pathophysiological alterations could cause significant elevations in PP and stiffening of arterial vessels, particularly in the elderly.

At the turn of the last century, the North American and European populations were ingesting about $450-550 \mathrm{mg} \mathrm{Mg} /$ day. $^{24,38-42}$ Today, about $70-75 \%$ of these populations are ingesting only about $165-$ 
$235 \mathrm{mg} \mathrm{Mg}$ /day. ${ }^{24,43}$ It has been shown, in multiple studies, that people drinking soft-water (e.g., $<10 \mathrm{mg} / \mathrm{l}$ of $\mathrm{Mg}$ /day) demonstrate a high risk for coronary arterial diseases, hypertension, hyper lipidemias, atherogenesis, and strokes, whereas those peoples drinking hardwaters (with high $\mathrm{Mg}$ levels, i.e., $>25 \mathrm{mg} / \mathrm{l}$ ) have low risks for these cardiovascular diseases. . $^{24,43}$

Importance of low $\mathrm{mg}$ environments in generation of ceramides and platelet-activation factor and inhibition of nitric oxide formation: relationship to rises in sbp and pp in drhs

Approximately 35 years ago, two of us reported that endothelial relaxation of isolated coronary arterial vessels required $\mathrm{Mg}^{2+}$, the greater the $\left[\mathrm{Mg}^{2+}\right]_{0}$, the greater the relaxation of the coronary vessels. ${ }^{44}$ In 1978,1984,and 1992, respectively, studying the intact intestinal and skeletal muscle microvasculatures in the rat, we reported that lowering the dietary level of $\mathrm{Mg}$ or the perfusate

$\left[\mathrm{Mg}^{2+}\right]_{0}$ resulted in vasoconstriction of arterioles (18-30 um), metarterioles (10-16 um) and precapillary sphincters (3-6 um). ${ }^{5,16,17}$ Some years later, studying the same intact microvasculatures, with low $\mathrm{Mg}$ levels, use of chemical inhibitors of nitric oxide synthases, resulted in vasodilation, reduced SBP and DBP, and reduced vasodilation when challenged with endothelial-dependent vasodilators such as acetylcholine and bradykinin, thus proving that $\mathrm{Mg}^{2+}$ is a key regulator of nitric oxide synthases and vasomotor tone in the peripheral microcirculation and PP. ${ }^{45}$

About 25 years ago, three of us, working with isolated cerebral and aortic vascular smooth muscle cells, and ${ }^{31} \mathrm{P}$-nuclear magnetic spectroscopy and ${ }^{1} \mathrm{H}$-nuclear magnetic resonance spectroscopy, we found that decreased extracellular $\mathrm{Mg}$ resulted in an increase in sphingolipids, particularly ceramides, sphingosine, and sphingosine$1-\mathrm{P} .{ }^{46,47}$ Further examination of the moieties revealed that low $\left[\mathrm{Mg}^{2+}\right]_{0}$ resulted in synthesis and release of platelet-activating factor (PAF) and PAF-like lipids. ${ }^{46}$ All of these sphingolipids and PAF can cause vasoconstriction/contraction of microvascular arterioles and muscular venules, as well as cerebral and coronary blood vessels. ${ }^{48-52}$

Approximately 25 years ago, using rats placed on $\mathrm{Mg}$-deficient diets for 21 days, we noted an increased release of ceramides, PAF, and PAF-like lipids into the blood stream..$^{25,38,39,46,47,51,52}$ Some years later, we found that cardiovascular tissues and cells excised from these Mg-deficient animals demonstrated increased levels of ceramides, SP-1-P; the greater the deficit in $\mathrm{Mg}^{2+}$, the greater the synthesis of sphingolipids, PAF and PAF-like lipids. ${ }^{51-60}$ Use of ceramide and PAF antagonists, in these Mg-deficient animals, not only reduced the ABP and PP, but reduced the vasoconstriction of intact arterioles and venules in the microcirculation. ${ }^{61}$ Overall, we believe that these experiments surely point to an important, if not critical role of $\mathrm{Mg}$, sphingolipids, PAF and PAF-like lipids. Recently, we found that elderly DRH and type 2 diabetic patients ( $>65$ years old) demonstrate increased serum levels of ceramides, SP-1-P, and PAF. ${ }^{62,63}$

\section{Progressive decrease of ionized magnesium results in a progressive down-regulation of telomerase: relation to epigenetic changes in the elderly}

Working with rats fed low $\mathrm{Mg}$ diets for 21 days, we have reported that cardiovascular tissues and cells showed peroxidation of vascular smooth muscle cells, a down-regulation of telomerases and oxidation of DNA. ${ }^{51-53,64-66}$ Using specific ELISA assays, we found that the extirpated cardiovascular tissues and cells showed that, as the ionized $\mathrm{Mg}$ fell in both the blood and cardiovascular tissues and cells, there was a progressive peroxidation, a down-regulation in telomerases and increases in oxidation of the DNA. ${ }^{51-53,64-66}$ Examination of elderly DRH subjects with elevated PP, also showed a down-regulation of telomerase in the sera along with deficits in ionized $\mathrm{Mg} .{ }^{63}$ Twenty-five years ago, using $\mathrm{Mg}$-deficient rabbits, we found that the atherogenesis (and plaques) that developed on the aortic and coronary arterial vessels became greater and greater with time on the Mg-deficient diets; invasion of the arterial walls showed alterations in the morphology of the macrophages and monocytes. ${ }^{70}$ We believe, overall, our experiments and elderly DRH -patient data suggest that even shortterm $\mathrm{Mg}$ deficiency, in the aging process, could cause alterations in the genome that would result in atherogenesis, stiffening of arterial and arteriolar vessels, DRH and increases in PP in the elderly.

\section{Roles of DNA oxidation and fragmentation, inflammation, and genotoxicity in $\mathrm{mg}$ deficiency and drh: importance in epigenetic processes}

Recently, we have reported that cardiovascular tissues and cells obtained from rats placed on $\mathrm{Mg}$-deficient diets for 21 days demonstrate a marked increase in 8-hydroxydeoxyguanosine, a reliable indicator of DNA oxidation; the lower the serum and cellular $\mathrm{Mg}^{2+}$, the greater the oxidation of DNA..$^{51,53,59,64-69}$ These results clearly support our contention that $\mathrm{Mg}$ deficiency probably leads to multiple mutations in the genomes of tissues and cells throughout the cardiovascular system. ${ }^{69}$ Previously, we found that only 21 days of $\mathrm{Mg}$ deficiency can result in DNA fragmentation and lipid peroxidation..$^{51,53,59,67}$

Although all cells in the body (except for red blood cells) continue to develop strategies to preserve the integrity of DNA structure, numerous factors can alter the structure of DNA, such as reactive oxygen (ROS) and nitrogen species (RNS), numerous extrinsic molecules, and UV radiation, to name a few. ${ }^{71-73}$ Each day, DNA of diverse mammalian tissues and cells (including cardiovascular components) receive multiple assaults from, for example, guanine methylations,

cytosine deaminations, spontaneous depurinations, single strand breaks, double strand breaks, and oxidative lesions, among others. ${ }^{71-78}$ Everyone of these insults induces specific damage of DNA. For example, external molecules can cause alkylation of DNA by methylnitrosourea. ${ }^{72,79}$ Cancer therapeutic agents such as mitomycin $\mathrm{C}$ and cisplatin can induce very-specific base modifications in the DNA, ${ }^{72,79}$ not surprisingly, both of these chemo-therapeutics cause profound depletion of body Mg. ${ }^{80,81}$ ROS and RNS can also induce very-specific base modifications in DNA. ${ }^{71-73,76-79,82-89}$ these agents also induce bodily depletion of $\mathrm{Mg}^{24,25,38,39,47,51,52,53,67,80,81} \mathrm{UV}$ light is known to induce strand breaks in DNA; wave lengths of this radiation can also induce bodily depletion of $\mathrm{Mg} .^{79}$ Interestingly, each one of these injurious assaults cause different DNA aberrations leading to different DNA-repair processes. ${ }^{73-79}$ Thus, each one of these assault species not only lead, in different ways, to alterations in DNA, but to different DNA-repair processes. ${ }^{73-79}$

Several years ago, using a short-term 21-day dietary Mg -deficient rat model, we reported that excised cardiovascular tissues and cells showed marked reductions in glutathione content and activation of eNOS and iNOS. ${ }^{88}$ Since eNOS-activation has been shown to activate 
synthesis of PAF in endothelial cells, our findings of low $\mathrm{Mg}^{2+}$-induced synthesis/generation of eNOS, in cardiovascular tissues and cells may trigger (and be linked), in part, to activation of the sphingomyelinaseceramide pathways. ${ }^{88}$ DNA damage and synthesis of DNA damage has been identified in human atherosclerosis. ${ }^{90,91}$ Thus, it is important to keep in mind, that both DNA damage and synthesis could be expected in diverse tissues and cells, depending upon time in low plasma $\mathrm{Mg}^{2+}$ environments to exert multiple phenotypic alterations in the biochemical machinery of endothelial and vascular smooth muscle cells, resulting in inflammatory responses, stiffening of blood vessels and elevations in ABP, SBP, and PP. In this context, we have shown that short-term Mg deficiency in rats leads to up-regulation of NF-kB and proto-oncogenes c-fos and c-jun, ${ }^{51,52,58,60,92}$ molecular pathways required for any alterations in phenotypic alterations of endothelial and vascular smooth muscle cells.

Approximately, ten years ago, we suggested that magnesiumdeficiency can act as a genotoxic agent..$^{54,55}$ One of ceramide's major physiological actions is its ability to induce cell differentiation and cell transformation, ${ }^{52,93-96}$ short-term $\mathrm{Mg}$ deficiency activates five different enzymatic pathways responsible for synthesis of ceramide in vascular smooth muscle cells. ${ }^{47,51,52,54-60,88}$ Such synthesis and release in Mg-deficient humans could aid in explaining, to a large extent, transformation of contractile vascular smooth muscle cells to a new phenotype in atherogenesis i.e., vascular muscle cells that no longer contract or relax, but become synthetic machines for a variety of cytokines, chemokines, and growth factors. ${ }^{52}$ Abnormal cell differentiation, transformation, and growth are pivotal events in the development of atherogenesis, hypertension, hyperlipidemia, and progressive cardiac failure.

\section{Conclusions and future thoughts}

Why there is an elevation in arterial blood pressure and a progressive rise of $\mathrm{ABP}$ and $\mathrm{PP}$ in drug-resistant hypertensive subjects (DRHs) has resulted in numerous hypotheses over the past 30 years. Why these DRHs cannot even be consistently treated with three different drugs also is not known. More than 40 years ago, our team, working with isolated arterial and arteriolar blood vessels found hat exposure of these vessels to physiologic salt solutions with reduced $\mathrm{Mg}^{2+}$ concentrations caused contraction and vasospasm which is dependent on extracellular and release of intracellular free $\mathrm{Ca}^{2+}$; the lower the free $\mathrm{Mg}^{2+}$, the greater the development of contractile force. Some years later, using intact rats placed on low $\mathrm{Mg}$ diets, we noted intestinal and skeletal microvessels went into spasm concomitant with increased constrictor activity to circulating neuro-humoral constrictor agents; ABP, SBP and PP rose the longer the animals ingested the low $\mathrm{Mg}$ diets., the greater the vasoconstriction of the microvessels, the greater the rise in PP. A combination of a low $\mathrm{Mg}$ diet and administration of nitric oxide inhibitors resulted in a potentiation of the vasospasms and potentiation of the arteriolar, metarteriolar and precapillary vasoconstrictions with markedly reduced capillary blood flows. Use of ${ }^{31} \mathrm{P}-\mathrm{NMR}$ spectroscopy and ${ }^{1} \mathrm{H}-\mathrm{NMR}$ spectroscopy on diverse vascular smooth muscle cells in low $\mathrm{Mg}^{2+}$ caused a synthesis and release of sphingolipids, PAF and PAF-like lipids. Use of inhibitors of ceramide and PAF in intact rats, given low $\mathrm{Mg}$ diets, ameliorated/inhibited the rises in SBP and PP.

Measurement of serum ceramides, sphingosine-1-P and PAF in DRHs revealed rises in these moieties, particularly in elderly patients (i.e., >65 years old). Rabbits placed on low Mg diets resulted in atherosclerotic arterial vessels (i.e., coronaries and aorta) with morphological alterations in the endothelial, monocytic and macrophage cells on the arterial walls. Cardiac and vascular smooth muscle cells excised from animals placed on low Mg diets show a down-regulation of telomerases, oxidation and fragmentation of DNA, activation of NF-kB, activation of proto-oncogenes, and an upregulation of five different enzymes leading to synthesis of ceramides Since the North American and European diets are low in dietary Mg, we believe our results on animals, cardiovascular tissues and cells and on human patients characterized as DRHs provide enough evidence to posit that low dietary intake of $\mathrm{Mg}$ probably plays an important role in DRH and elevated PP, particularly as these subjects age.

\section{Acknowledgments}

Most of the studies mentioned herein were supported by research grants from The N.I.H. (NationalHeart, Lung and Blood Institute; National Institute on Drug Abuse; National Institute on Alcoholism and Alcohol Abuse; National Institute on Mental Health); unrestricted pharmaceutical company grants-in-aid (The UpJohn Co; Sandoz Pharmaceuticals; CIBA-Geigy Corp; Bayer Pharmaceuticals; and Warner-Lambert Pharmaceuticals); and interested donors to BMA and BTA.

\section{Conflicts of interest}

The author declares there are no conflicts of interest.

\section{References}

1. Intengan HD, Schriffrin EL. Vascular remodeling in hypertension: roles of apoptosis, inflammation and fibrosis. Hypertension. 2001;38(3 pt 2):581-587.

2. Mulvany MJ. Small artery remodeling and significance in the development of hypertension. News Physiol Sci. 2002;17(3):105-109.

3. Altura BM, Altura BT. Influence of magnesium on drug-induced contractions and ion content in rabbit aorta. Am J Physiol. 1971;220:938-944.

4. Altura BM, Altura BT. Magnesium and contraction of arterial muscle. Microvasc Res. 1974;7:145-155.

5. Altura BM, Altura BT. Magnesium and vascular tone and reactivity. Blood Vessels. 1978;15:5-16.

6. Altura BM. Magnesium withdrawal and rhythmic contractility of arterial vs. venous smooth muscle: differential effects of multivalent cations and EDTA. Artery. 1978;4:512-527.

7. Altura BM. Sudden-death ischemic heart disease and magnesium deficiency: is the target site coronary vascular smooth muscle? Med Hypoth. 1979;5:843-849.

8. Turlapaty PDMV, Altura BM. Magnesium deficiency produces spasms of coronary arteries: relationship to etiology of sudden death ischemic heart disease. Science. 1980;208:198-200.

9. Altura BT, Altura BM. Withdrawal of magnesium causes vasospasm while elevated magnesium produces relaxation of tone in cerebral arteries. Neurosci Lett. 1980;20:323-327.

10. Altura BM, Altura BT. Magnesium ions and contraction of vascular smooth muscles; Relationship to some vascular diseases. Federation Proc. 1981;40:2672-2679. 
11. Turlapaty PDMV, Weiner R, Altura BM. Interactions of magnesium and verapamil on tone and contractility of vascular smooth muscle. Eur $J$ Pharmacol. 1981;74:263-272.

12. Altura BM, Altura T, Carella A, et al. Hypomagnesemia and vasoconstriction: Possible relationship to etiology of sudden death ischemic heart disease and hypertensive vascular vascular diseases. Artery. 1981;9:212-231.

13. Altura BM, Turlapaty PDMV. Withdrawal of magnesium enhances coronary arterial spasms produced by vasoactive agents. Brit J Pharmacol. 1982;77:649-659.

14. Altura BT, Altura BM. The role of magnesium in etiology of strokes and cerebrovasospasm. Magnesium: exp Clin res. 1982;1:277-291.

15. Altura BM, Altura BT, Carella A. Magnesium deficiency-induced spasms pf umbilical vessels: Relation to preeclampsia, hypertension, growth retardation. Science. 1983;221:376-378.

16. Altura BM, Altura BT, Gebrewold A, et al. Magnesium deficiency and hypertension: correlation between magnesium deficiency and microcirculatory changes in situ. Science. 1984;223(4642):1315-1317.

17. Altura BM, Altura BT, Gebrewold A, et al. Noise-induced hypertension and magnesium in rats: relationship to microcirculation and calcium. $J$ Appl Physiol. 1992;72(1):194-202.

18. Luthringer C, Rayssiguier $\mathrm{Y}$, Gueux E, et al. Effect of magnesium deficiency on serum lipids, blood pressure and cardiovascular reactivity. Br J Nutr. 1988;59(2):243-250.

19. Laurant P, Hayoz D, Brunner HR, et al. Effect of magnesium deficiency on blood pressure and mechanical properties of rat carotid artery. Hypertension. 1999;33(5):1105-1110.

20. Marcus JC, Valencia JB, Altura BT, et al. Serum ionized magnesium in premature and term infants. Pediatr Neurol. 1998;18(4):311-314.

21. Munoz R, Wessel DR, G Palacio, et al. Whole blood ionized magnesium: age-related differences in normal values and clinical implications of ionized hypomagnesemia in patients undergoing surgery for congenital cardiac diseases. J Thor and Cardiovasc Surg. 2000;119(5):891-899.

22. Barbagallo M, Belvedere M, Dominguez LJ. Magnesium metabolism and aging. Magnesium Res. 2000;22(4):235-246.

23. Barbagallo M, Di Bella G, Brucato V, et al. Serum ionized magnesium in older persons. Metabol. 2014;63(4):502-509.

24. Dean C. The Magnesium Miracle. Ballantine Books, New York. 2014

25. Altura BM, Li W, Zhang A, et al. Sudden cardiac death in infants, children and young adults: possible roles of dietary magnesium intake and generation of platelet-activating factor in coronary arteries. $J$ Heart Health. 2016;2:2.

26. Altura BM, Altura BT. Importance of ionized magnesium measurements in physiology and medicine and the need for ion-selective electrodes. $J$ Clin Case Studies. 2016;1(2).

27. Altura BM, Lewenstam A. Unique Magnesium Ion-Selective Electrodes Scand J Clin Lab Invest. 1994;54(Supp1 217):1-100.

28. Altura BT, Altura BM. Measurement of ionized magnesium in whole blood, plasma and serum with a new ion-selective electrode in healthy and diseased human subjects. Magnes Trace Elem. 1991;10(2-4):90-98.

29. Handwerker SM, Altura BT, Royo B, et al. Ionized magnesium and calcium kevels in umbilical cord serum of pregnant women with transient hypertension during labor. Am J Hypertens. 1993;6(6 pt 1):542-545.

30. Resnick LM, Altura BM, Gupta RK, et al. Intracellular and extracellular magnesium depletion in type 2 (non-insulin-dependent) diabetes Mellitus. Diabetologia. 1993;36(8):767-770.
31. Altura BM, Altura BT. Role of magnesium in patho-physiological processes and the clinical utility of magnesium ion-selective electrodes. Scand J Clin Lab Invest Suppl. 1996;224:211-234.

32. Bardicef M, Bardicef O, Sorokin Y, et al. Extracellular and intracellular magnesium depletion in pregnancy and gestational diabetes. Am J ObstetGynecol. 1995;172(3):1009-1013.

33. Scott VL, DeWolf AM, Kang Y, et al. Ionized hypomagnesemia in patients undergoing orthotopic liver transplantation: a complication of citrate intoxication. Liver Transpl and Surg. 1996;2(5):343-347.

34. Resnick LM, Bardicef O, Altura BT, et al. Serum ionized magnesium: relation to blood pressure and racial factors. Am J Hypertens. 1997;10(12 pt 1):1420-1424.

35. Markell MS, Altura BT, Barbour RL, et al. Ionized and total magnesium levels in cyclosporin-treated renal transplant recipients: relationship with cholesterol and cyclosporin levels. Clin Sci. 1993;85(3):315-318.

36. Markell MS, Altura BT, Sarn Y, et al. Deficiency of serum ionized magnesium in patients receiving hemodiaysis or peritoneal dialysis. ASAIO J. 1993;39(3):891-804.

37. Altura BT, Burack JL, Cracco RQ, et al. Clinical studies with the NOVA ISE for IMg ${ }^{2+}$. Scand J Clin Lab Invest. 1994;54(Suppl 217):53-67.

38. Altura BM, Altura BT. Magnesium and cardiovascular biology: an important link between cardiovascular risk factors and atherogenesis. Cell Mol Biol Res. 1995;41(5):347-359.

39. Altura BM, Altura BT. Magnesium in cardiovascular biology. Sci Am Sci \& Med. 1995;2(3):28-37.

40. Altura BM, Altura BT. Role of magnesium in the pathophysiology of hypertension updated: relationship to its actions on cardiac, vascular smooth muscle, and endothelial cells. In: Laragh JH, Brenner BM, editors. Hypertension: Pathophysiology, Diagnosis, and Management, $2^{\text {nd }}$ ed. 1995.

41. Ford ES, Mokdad AH. Dietary magnesium in a national sample of US adults. J Nutr. 2003;133(9):2879-2882.

42. Mosfegh A, Goldman J, Abuja J, et al. What We Eat in America, NHANES 2005-2006: Usual Intakes from Food and Water Compared to 1997 Dietary Reference Intakes for Vitamin D, Calcium, Phosphorus, and Magnesium. Washington, DC, US Department of Agricultural Research Service. 2009.

43. Altura BM, Zhang A, Murakawa T, et al. Can hypomagnesemia put the squeeze oncoronary arteries: An unappreciated factor in myocardial ischemia, heart attacks and sudden cardiac death. EC Orthopaedics. 2019;10(7):572-581.

44. Altura BT, Altura BM. Endothelium-dependent relaxation in coronary arteries requires magnesium ions. Brit J Pharmacol. 1987;91(3):149-151.

45. Yang ZW, Gebrewold A, Nowakowski M, et al. $\mathrm{Mg}^{2+}$-induced endothelium -dependent relaxation of blood vessels and blood pressure lowering: role of NO. Am J Physiol RegulIntegr Comp Physiol. 2011;278:628-639.

46. Morrill GA, Gupta RK, Kostellow AB, et al. $\mathrm{Mg}^{2+}$ modulates membrane lipids in vascular smooth muscle: a link to atherogenesis. FEBS Lett 1997;408(2):191-197.

47. Morrill GA, Gupta RK, Kostellow AB, et al. $\mathrm{Mg}^{2+}$ modulates membrane sphingolipids and lipid second messengers in vascular smooth muscle cells. FEBS Lett. 1998;440(1-2):167-171.

48. Zheng T, Li W, Altura BT, et al. Sphingomyelinase and ceramide analogs induce contraction and rises in $\left[\mathrm{Ca}^{2+}\right]_{\mathrm{I}}$ in canine cerebral vascular muscle. Am J Physiol Heart Circ Physiol. 2000;278(5):1421-1428.

49. Bischoff A, Czyborra B, Fetscher C, et al. Sphingosine-1-phosphate and sphingosylphorylcholineconstrict renal and mesenteric microvessels. Brit J Pharmacol. 2000;130(8):1871-1877.

Citation: Altura BM, Gebrewold A, Carella A, et al.Why it is difficult to treat and prevent drug-resistant hypertension and elevated pulse pressure: the unrecognized roles of ionized hypomagnesemia, nitric oxide, ceramides, platelet-activating factor,and epigenesis. Int J Mol Biol Open Access. 2020;5(2):53-58. DOI: I0.I5406/ijmboa.2020.05.00132 
50. Altura BM, Gebrewold A, Zheng T, et al. Sphingomyelinase and ceramide analogs induce vasoconstriction and leukocyte-endothelial interactions in cerebral blood venules in the intact rat brain: insight into mechanisms and possible relation to brain injury and stroke. Brain Res Bull. 2000;58(3):271-278.

51. Altura BM, Shah NC, Shah GJ, et al. Magnesium deficiency, sphingolipids, and telomerase: relevance to atherogenesis, cardiovascular diseases, and aging. In: Preedy V, Patel, eds. Handbook of Starvation, Famine and Nutrients, Springer, Berlin, 2018.

52. Altura BM, Li W, Zhang A, et al. The expression of platelet-activating factor is induced by low extracellular $\mathrm{Mg}^{2+}$ in aortic, cerebral and neonatal coronary vascular smooth muscle; cross-talk with ceramide production, NF-kB and proto-oncogenes: Possible links to atherogenesis and sudden cardiac death in children and infants, and aging: Hypothesis, review and viewpoint. Int J Cardiol and Res. 2016;3(1):47-67.

53. Altura BM, Shah NC, Jiang XC, et al. Short-term magnesium deficiency results in decreased levels of serum sphingomyelin, lipid peroxidation, and apoptosis in cardiovascular tissues. Am J Physiol Heart Circ Physiol. 2009;297(1):86-92.

54. Altura BM, Shah NC, Li Z, et al. Magnesium deficiency upregulates serine palmitoyltransferase (SPT 1 and SPT 2) in cardiovascular tissues: relationship to serum ionized $\mathrm{Mg}$ and cytochrome C. Am J Physiol Heart Circ Physiol. 2010;299(3):932-938.

55. Altura BM, Shah NC, Li W, et al. Short-term magnesium deficiency upregulates sphingomyelin synthase and p53 in cardiovascular tissues and cells: relevance to the de novo synthesis of ceramide. Am J Physiol Heart Circ Physiol. 2010;299(6):2046-2055.

56. Shah $\mathrm{NC}$, Liu JP, Iqbal $\mathrm{J}$, et al. Mg deficiency results in modulation of serum lipids, glutathione, and NO synthase isozyme activation in cardiovascular tissues: relevance to de novo synthesis of ceramide, serum Mg and atherogenesis. Int J Clin Exp Med. 2011;4(2):103-118.

57. Altura BM, Shah NC, Shah GJ, et al. Short-term magnesium deficiency upregulates ceramide synthase in cardiovascular tissues and cells: crosstalk among cytokines, $\mathrm{Mg}^{2+}, \mathrm{NF}-\mathrm{kB}$ and de novo ceramide. Am J Physiol Heart Circ Physiol. 2012;302(1):319-332.

58. Altura BM, Shah NC, Shah GJ, et al. Magnesium deficiency upregulates sphingomyelinases in cardiovascular tissues and cells: cross-talk among proto-oncogenes, $\mathrm{Mg}^{2+}, \mathrm{NF}-\mathrm{kB}$, and ceramide and their relationships to resistant hypertension, atherogenesis and cardiac failure. Int J Clin Exp Med. 2013;6(10):861-879.

59. Shah NC, Shah GJ, Li Z, et al. Short-term magnesium downregulates telomerase, upregulates neutral sphingomyelinase and induces oxidative DNA damage in cardiovascular tissues: relevance to atherogenesis, cardiovascular diseases and aging. Int J Clin Exp Med. 2014;7(3): 497514.

60. Altura BM, Shah NC, Shah GJ, et al. Mg deficiency upregulates protein kinase $\mathrm{C}$ isoforms in cardiovascular tissues and cells; relation to NF$\mathrm{kB}$, cytokines, ceramide salvage sphingolipid pathway and PKC-zeta: hypothesis and review. Int J Clin Exp Med. 2014;7(1):1-21.

61. Altura BM, GebrewoldA, Carella A, et al. Inhibitors of ceramide and PAF ameliorate vasoconstriction of arterioles, precapillary sphincters and muscular venules induced by dietary magnesium deficiency: elevated arterial blood pressure and pulse pressure also modulatedby the inhibitors. 2020.

62. Altura BM, Carella A, Gebrewold A, et al. Why there is an increased risk of cardiac failure, widening of pulse pressure and hemorrhagic stroke in type 2 diabetics over age 60 : Roles of unrecognized hypomagnesemia and epigenetics coupled with increased levels of ceramides, cytokines, ROS, 4-HNE and platelet-activating factor. J Clin Case Studies. 2020;5(2)
63. Altura BM, Gebrewold A, Carella, et al. Importance of serum levels of ionized $\mathrm{Mg}$, ceramide and PAF in elderly drug-resistant hypertensive patients. 2020 .

64. Wu F, Altura BT, Gao J, et al. Ferrylmyoglobin formation induced by acute magnesium deficiency in perfused rat heart causes cardiac failure. BiochimBiophys Acta. 1994;1125(2):158-164.

65. Altura BM, Altura BT. Magnesium metabolism, atherogenesis and cardiovascular pathobiology. In: Smetana R, editor. Advances in Magnesium Research. 1997;28-38.

66. Altura BM, Altura BT. Mg and atherogenesis. In: Theophanides T, Anastassopoulaou I, editors. Magnesium: Current Status and New Developments. 1997;385-397.

67. Altura BM, Gebrewold A, Zhang A, et al. Low extracellular magnesium induces lipid peroxidation and activation of nuclear factor-kB in canine cerebral vascular smooth muscle: possible relation to traumatic brain injury and stroke. Neurosci Lett. 2003;341(3):189-192.

68. Altura BM, Shah NC, Shah GJ, et al. Magnesium deficiency results in oxidation and fragmentation of DNA, downregulation of telomerase activity, and ceramide release in cardiovascular tissues and cells: Potential relationship to cardiovascular diseases and aging. Int J DiabetolVasc Dis. 2016;4:1-5.

69. Altura BM, Shah NC, Shah GJ, et al. Genotoxic effects of magnesium deficiency in the cardiovascular system and their relationships to cardiovascular diseases and atherogenesis. Cardiovasc Dis \& Diagn 2016.

70. Altura BT, Brust M, Bloom S, et al. Magnesium dietary intake modulates blood lipid levels and atherogenesis. Proc Nat Acad Sci USA. 1990;87(5):1840-1844.

71. Kasai H. Analysis of a form of oxidative DNA damage as a marker of cellular oxidative stressduring carcinogenesis. Mutat Res. 1997;387(3):147-163.

72. Jenner A, England G, Aruoma OI, alliwellalliwellet al. Measurement of oxidative DNA damage by gas chromatography-mass spectrometry : ethanethiol prevents artificial generation of oxidized DNA bases. Biochem J. 1998;332(Pt 2):365-369.

73. Lee SH, Blair A. Oxidative DNA damage and cardiovascular disease. Trends Cardiovasc Med. 2001;11(3-4):148-155.

74. Jackson JP, Bartek J. The DNA-damage response in human biology and disease. Nature. 2009;461(7267):1071-1078.

75. Halliwell B. Why and how should we measure oxidative DNA damage in nutritional studies? How far have we come? Am J Clin Nutr. 2002;72(5):1082-1087.

76. Ecki PM. Genotoxicity of HNE. Mol Aspects of Med. 2003;24(4-5):161165.

77. Fruwirth GO, Loidi A, Hermetter A. Oxidized phospholipids: From molecular properties to disease. Biochim Biophys Acta. 2007;1772(7):718 736.

78. Mehta A, Haber JE. Sources of DNA double- strand breaks and models of recombinational DNA repair. Cold Spring Harbor Perspectives Biol. 2014;6(9):a016428

79. McDonald OG, Owens GK. Programming smooth muscle plasticity with chromatin dynamics. Circ Res. 2007;100(10):1428-1441.

80. Altura BM, Altura BT. New perspectives on the role of magnesium in the pathophysiology of the cardiovascular system. I. Clinical aspects. Magnesium: Exp Clin res. 1985;4(5-6):226-244. 
81. Altura BM, Shah NC, Shah GJ, et al. Why do chemotherapeutic drugs and radiation induce cardiomyopathy and cardiac failure in cancer patients: Is this a consequence of unrecognized hypomagnesemia and release of ceramides and platelet-activating factor? Sci Fed J Emerg Med. 2017;1(1).

82. Wu F, Zou LY, Altura BT, et al. Low extracellular magnesium results in cardiac failure in isolated perfused rat hearts. Magnes Trace Elem. 19911992;10(5-6):364-373.

83. Dickens BF, Weglicki WB, Li YS, et al. Magnesium deficiency in vitro enhances free radical-induced intracellular oxidation and cytotoxicity in endothelial cells. FEBS Lett. 1992;311(3):187-191.

84. Altura BM, Gebrewold A, Altura BT, et al. Magnesium depletion impairs myocardial carbohydrate and lipid metabolism and cardiac bioenergetics and raises myocardial calcium content in-vivo: relationship to etiology of cardiac diseases. BiochemMolec Biol Int. 1996;40(6):1183-1190.

85. Gueux E, Azais-Braesco V, Bussiere L, et al. Effect of magnesium deficiency $n$ triacylglycerol-rich lipoprotein and tissue susceptibility to peroxidation in relation to vitamin E content. Br J Nutr. 1995;74(6):849856.

86. Bussiere FI, Gueux E, Rock E, et al. Increased phagocytosis and production of reactive oxygen species by neutrophils during magnesium deficiency in rats and inhibition by high magnesium concentrations. $\mathrm{Br} J$ Nutr. 2002;87(2):107-113.

87. Wolf FI, Trapani V, Maier JAM. Magnesium deficiency and endothelial dysfunction: is oxidative stress involved? Magnes Res. 2008;21(1):58-64.

88. Shah NC, Liu JP, Iqbal Hussain $\mathrm{M}$, et al. Mg deficiency results in modulation of serum lipids, glutathione, and NO synthase isozyme activation in cardiovascular tissues: relevance to de novo synthesis of ceramide, Mg and atherogenesis. Int J Clin Exp Med. 2011;4(2):103-118.
89. Barbagallo M, Dominguez E. Chapter 16. Magnesium, oxidative stress, and aging. In: Aging-Oxidative Stress and Dietary Antioxidants. New York: Elsevier; 2014:157-166.

90. Gray K, Kumar S, Figg N, et al. Effects of DNA damage in smooth muscle cells in atherosclerosis. Circ Res. 2015;116(5):816-826.

91. Razani B, Raines EW. Can the DNA damage response be harnassed to modulate atherosclerotic plaque phenotype. Circ Res. 2015;116(5):770 773.

92. Altura BM, Kostellow AB, Zhang A, et al. Expression of the nuclear factor-kB and proto-oncogenes c-fos and c-jun are induced by low extracellular $\mathrm{Mg}^{2+}$ in aortic and cerebral vascular smooth muscle cells: possible links to hypertension, atherosclerosis, and stroke. $\mathrm{Am} \mathrm{J}$ Hypertens. 2003;16(9):701-709.

93. Andrieu-Abadie N, Gouaze V, Salvayre R, et al. Ceramide in apoptosis signaling: relationship with oxidative stress. Free Radic Biol Med. 2001;31(6):717-728.

94. Auge N, Andrieu N, Negre-Salvayre R, et al. Sphingomyelin metabolites in vascular signaling and atherosclerosis. Prog Lipid Res. 2000;39(3):207239.

95. Kolesnick R. Signal transduction through the sphingomyelin pathway. Mol Chem Neuropath. 1994;21(2-3):298-309.

96. Pandey S, Murphy RF, Agrawal DK. Recent advances in the immunobiology of ceramide. Exp Mol Pathol. 2007;82(3):298-309. 